\title{
Anti-inflammatory Activity of Pegagan Embun (Hydrocotyle sibthorpioides Lam.) Plant Extract on Topical Application
}

\author{
Afriwardi ${ }^{1, *}$, Rahmatul Nazmi ${ }^{2}$, Dwisari Dillasamola ${ }^{2}$, Elsa Badriyya ${ }^{2}$, Yufri Aldi ${ }^{2}$
}

\author{
Afriwardi ${ }^{1, *}$, Rahmatul Nazmi ${ }^{2}$, \\ Dwisari Dillasamola², Elsa \\ Badriyya $^{2}$, Yufri Aldi
}

${ }^{1}$ Faculty of Medicine, Andalas University, INDONESIA.

${ }^{2}$ Faculty of Pharmacy, Andalas University, INDONESIA.

\section{Correspondence}

\section{Afriwardi}

Faculty of Medicine, Andalas University, INDONESIA.

E-mail : afriwardi@med.unand.ac.id History

- Submission Date: 19-12-2020;

- Review completed: 11-01-2021;

- Accepted Date: 29-01-2021.

DOI : 10.5530/pj.2021.13.52

Article Available online http://www.phcogj.com/v13/i2

\section{Copyright}

(C) 2021 Phcogj.Com. This is an openaccess article distributed under the terms of the Creative Commons Attribution 4.0 International license.

\begin{abstract} $2 \%$, has an anti-inflammatory effect. Leukocytes.

\section{INTRODUCTION}

Indonesia is one of the mega-biodiversity countries that is known as a storehouse of medicinal plants. There are approximately 30,000 species of flora found in Indonesia's tropical forests. About 9,600 species have been known to be medicine. ${ }^{1}$ Since ancient times, medicinal plants processed as folk remedies have been widely used by Indonesians, both in the form of fresh single, mixed, and herb that is better known as traditional medicine or herbal medicine. Since time immemorial, people have commonly used traditional medicine, so traditional medicine is relatively safe for human consumption.
\end{abstract}

Introduction: Pegagan embun (Hydrocotyle sibthorpioides Lam.) is traditionally known to have many benefits, including anti-inflammatory. Aims: This study aimed to determine the activity of ethanol extract of Pegagan Embun as an anti-inflammatory using the granuloma pouch method. Methods: This experiment used 25 male white mice and were divided into five groups, namely, the positive control group, Hydrocotyle sibthorpioides Lam. extract group with concentration $0.5 \% ; 1 \% ; 2 \%$, and the comparison group that given Kaltrofen $®$ gel containing $2.5 \%$ ketoprofen. Experimental animals were given carrageenan $2 \%$ to induced the inflammation subcutaneously. The dosage form was given as much as $0.2 \mathrm{~g}$ topically for four days once a day. Results: Based on the results of one-way ANOVA analysis and Duncan's test, there were significant differences in exudate volume and total leukocytes $(p<0.05)$ in the positive control group, extract with concentration $0.5 \%, 1 \%, 2 \%$, and the comparator. While the percentage of leukocyte cells showed that they were not significantly different $(p>0.05)$, the number of neutrophil cells decreased. Conclusion: From the overall data obtained, it can be concluded that the extract of Hydrocotyle sibthorpioides Lam. at concentration $0.5 \%$; $1 \%$;

Key words: Hydrocotyle sibthorpioides Lam., Gel, Anti-inflammatory, Ketoprofen, Exudate,

Nevertheless, scientific proof is still necessary to ensure its safety. Medicinal plants with potential began to be developed, and some categorized as wild plants have been identified and showed the results of 48 types of weed vegetation from 27 families. One of the wild plants with medicinal properties is ( Hydrocotyle sibthorpioides Lam.). ${ }^{2}$ Hydrocotyle sibthorpioides Lam. is a medicinal plant that grows creeping, lean, fertile in moist, open, or shady places on the roadside, sewer edges, grass courts ${ }^{3}$ and has been used traditionally to treat various diseases. Quamar and Bera (2014) reported that Hydrocotyle sibthorpioides Lam. used for stomachic disorders and carminatives ${ }^{4}$ The juice of the plant in the treatment of fevers is applied externally on wounds and boils. The decoction of the whole plant is used in the treatment of abscess, cirrhosis, cough, hepatitis, itching, jaundice during the extract of Hydrocotyle sibthorpioides Lam.
Reported to have analgesic, anxiolytic, sedative, and anti-inflammatory effects in mice. ${ }^{5}$

Hydrocotyle sibthorpioides Lam. contain of chemical properties such as oleanane-type triterpenes (like Hydrocotyloside I-III, Ranuncoside I-V, barrigenol derivatives, phenolics (like chlorogenic acid, dehydrotriferulIC acid) and flavonoids (like quercetin retinoside, quercetin 3-O-glucoside $)^{5}$ quersetin $3-\mathrm{O}-\beta-\mathrm{D}$ ( $6^{\prime \prime}-$ caffeoylgalactoside) Terpen especially trans- $\beta$-farnesene. ${ }^{6}$ Subsequent research reported that Pegagan embun contain seven triterpenoid saponin compounds, one of them is udosaponin $\mathrm{B}^{7}$ essential oils, kumarin and hyperin ${ }^{8}$ and terpenoid content of essential oils (trans- $\beta$ farnesene, $\beta$-pinene, $\alpha$-pinene, $\beta$-caryophyllene, $\alpha$-humulene, camphene, and ocimene expressed in monoterpenoids and sesquiterpenoids). ${ }^{9}$

Based on the above description, research was conducted to study the anti-inflammatory activity of Hydrocotyle sibthorpioides Lam. ethanol extract given topically to mice. This study's inflammatory method was a granuloma pouch with parameters observed in anti-inflammatory activity to calculate the decrease in the volume of edema formed in the mice and monitor the total number of leukocytes cells and the percentage of leukocytes cells in the mice.

\section{MATERIALS AND METHODS}

Time and place

This research was conducted from January 2020 - May 2020 in the Research laboratory and Pharmacology

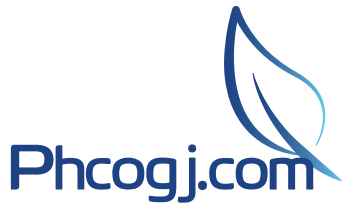

Cite this article: Afriwardi, Nazmi R, Dillasamola D, Badriyya E, AldiY. Anti-inflammatory Activity of Pegagan Embun (Hydrocotyle sibthorpioides Lam.) Plant Extract on Topical Application. Pharmacog J. 2021;13(2): 411-7. 
Laboratory of the Faculty of Pharmacy, Andalas University.

\section{Tools}

The tools used in this study were $5 \mathrm{~mL}$ (One Med) syringes, $1 \mathrm{~mL}$ (One Med) syringes, surgical scissors, mortar and pestle, scales, glass tools (drip pipettes, measuring glasses, beaker glass, bottles), rotary evaporators, and water baths, distillation tools, glass objects, tissues, markers, microscopes (Zeiss), hemocytometer, and pH meters (Mettler Toledo)

\section{Materials}

The materials used are Pegagan Embun (Hydrocotyle sibthorpioides Lam.), ethanol 70\% (Indomedifa), hexane (Indomedifa), ethyl acetate (Indomedifa), carrageenan (Sigma-Aldrich), Ketoprofen gel 2.5\% (Kaltrofen ${ }^{\odot}$ ), carbopol 934 (Hangzhou Lingeba Technology Co.,LTD, China), $\mathrm{t}$ triethanolamine (Petronas Chemicals), glycerine (Brataco), aqua dest, fur thresher cream (Veet ${ }^{\circledR}$ ) and Giemsa solution (SigmaAldrich).

\section{Sampling and identification}

Hydrocotyle sibthorpioides Lam. was obtained from Alahan Panjang, West Sumatra. Plant identification has been carried out at Herbarium Universitas Andalas (ANDA) Department of Biology Faculty of MIPA, Andalas University Padang with identification number 033/K-ID/ ANDA/I/2020

\section{Manufacture}

A total of $3.5 \mathrm{~kg}$ of Hydrocotyle sibthorpioides Lam. has been blended, macerated using $70 \%$ ethanol. Then put one part of the dry powder simplicia into the macerator, added ten parts solvent. Then, soaked for the first six hours while occasionally stirring, let stand for 18 hours. Macerate is filtered. This extraction process is repeated three times using the same type and number of solvents. Collect all the macerate, then steam them with a rotary evaporator until a viscous extract is obtained. ${ }^{9}$

\section{Dosage form test preparation}

The gel was made in four formulas, gel base without active substance and gel with $H$. sibthorpioides ethanol extract in $0,5 \% ; 1 \%$; and $2 \%$ concentrations

\section{Induction solution manufacturing}

Weigh the carrageenan as much as $1 \mathrm{~g}$, then crushed finely in the mortar. Add oleum sesami $50 \mathrm{~mL}$ until the concentration of carrageenan obtained is $2 \% .^{10}$

\section{Testing anti-inflammatory activity with granuloma pouch method}

The mice's back hair was shaved with a diameter of $\pm 3 \mathrm{~cm}, 24$ hours before treatment. The shaved back is injected with air as much as 5 $\mathrm{mL}$ subcutaneously until the airbag is formed. Then, at the same time, injected $0.1 \mathrm{~mL}$ of carrageenan. After 24 hours, the airbag was sucked with a syringe $5 \mathrm{~mL}$ so that the airbag becomes deflated. Then add a $2 \%$ carrageenan solution as much as $0.5 \mathrm{~mL}$ to the airbag's existing place. The test preparation is given by applying evenly to the airbag area immediately after administration of $0.5 \mathrm{~mL}$ carrageenan. ${ }^{10}$ The experimental animal group was each given the following test, the positive control group was given a gel base with no active substance, the test group was given Hydrocotyle sibthorpioides Lam. extract with concentration $0.5 \% ; 1 \% ; 2 \%$, and therefore the comparison group was given Kaltrofen ${ }^{\bullet}$ gel containing $2.5 \%$ ketoprofen. The dosage form was given as much as $0.2 \mathrm{~g}$ topically for four days once a day. Exudate volume measurement is carried out on the 5th day. Exudate is taken by cutting the bag vertically and collected using a syringe and then measured the volume and calculated the percentage of inhibition of its exudate formation.

$\%$ Inhibition of Exudate Formation $=\frac{v c-v u}{v c} \times 100 \%$

Note: $\quad \mathrm{Vc}=$ exudate Volume of control animal

$\mathrm{Vu}=$ exudate volume of the test animal

\section{Calculation of leukocyte cell percentage}

The calculation of the percentage of leukocyte cells is carried out by taking one drop of exudate mice placed on the glass of the object and flattening with the other object's glass to obtain exudates' slide, then dry. Once dry, drip with methanol. It coats the entire exudate remover and leaves for 5 minutes. Then add one drop of Giemsa solution and leave for 20 minutes. Wash with distilled water, dry it and look under a microscope with $1000 \mathrm{x}$ magnification. Count the number of eosinophils, neutrophil segments, neutrophil stems, lymphocytes, and monocytes in exudate wipes. ${ }^{11}$

\section{Calculation of the total number of leukocytes}

The calculation of the total number of leukocyte cells is carried out by taking exudate's mice and then sucking with leukocyte pipettes up to the number 0.5 , then sucking the Turk solution up to the mark of 11 . Whisk for 3 minutes, then discard 1-2 drops and drop 1 sample drop on the room count hemocytometer. Leave for 2 minutes for the leukocytes to settle. Count the number of leukocytes in all four corners of the room count by the formula: ${ }^{12}$

Total number of leukocytes $=$ number of leukocytes $x \frac{20}{0,4}$

\section{Data analysis}

Edema volume data and percentage data of leukocyte cells (neutrophils stems, neutrophil segments, eosinophils, monocytes, and lymphocytes) were statistically analyzed using a one-way variation analysis (ANOVA) followed by the Duncan test.

\section{RESULTS AND DISCUSSION}

Maceration is carried out using ethanol solvents. The sample is macerated for $3 \times 24$ hours; then, the results were tightened with rotary evaporator until obtained viscous extract. The extraction process obtained $98.53 \mathrm{~g}$ of viscous ethanol extract and $11.61 \%$ extract rendemen. Determination of the group of active compounds contained in the extract is carried out by color action. The results showed that it had groups of flavonoid, phenolic, and saponin compounds (Table 1).

Analysis using TLC is the separation of chemical components based on the principle of adsorption and partitions determined by the silent phase (adsorbent) and motion phase (eluent). Chemical components move up following the motion phase because the adsorbent absorption of chemical elements is not the same. Chemical elements can move at different distances based on their level of polarities. ${ }^{13}$ This is what causes the separation of chemical components in the extract. Analysis

Table 1: Identification results with color reacting.

\begin{tabular}{ccccc}
\hline No. & Examination & Reactor & $\begin{array}{c}\text { Observation } \\
\text { result }\end{array}$ & Result \\
\hline 1. & Flavonoids & $\begin{array}{c}\text { Mg Powder and } \\
\text { Concentrated HCL } \\
\text { Hot water and 2N } \\
\text { HCL }\end{array}$ & Yellow solution & + \\
2. & Saponins & $\begin{array}{c}\text { Formed froth } \\
\text { Fe Cl }\end{array}$ & $\begin{array}{c}\text { Blackish green } \\
\text { solution }\end{array}$ & + \\
3. & Phenolic & $\mathrm{Fen}_{3}$ & + \\
\hline
\end{tabular}


of the TLC on the extract is carried out by splatter it on the TLC plate which is enticed with the motion phase of hexane: ethyl acetate with a ratio of 6:4. The results seen under UV light of $254 \mathrm{~nm}$ showed a stain with an Rf value of 0.51. (Figure 1).

The experimental animal used is a male white mice. Male gender selection is intended for uniformity in research. Before the experiment, mice in acclimatization first for seven days to choose healthy mice and can familiarize themselves with the new environment. The mice used is healthy mice, do not show any significant weight changes (maximum deviation of 10\%), and visually exhibit normal behavior. The 25 eligible test animals were divided into five groups: one positive control group, one comparison group, and three test groups. Each group consists of 5 mice

After measuring the gel's anti-inflammatory activity, it can be seen from the data of the decrease in exudate volume in Figure 2. The largest average drop in exudate volume was in gel extract concentrations of $2 \%, 0.28 \mathrm{~mL}$.

Based on the one-way ANOVA statistical analysis results from giving The gel of extract Hydrocotyle sibthorpioides Lam. at a concentration of $0.5 \%$ to $2 \%$, the exudate volume was significantly reduced $(\mathrm{p}<0.05)$. The results indicate that the Hydrocotyle sibthorpioides Lam. extract gel can inhibit inflammation reaction. Furthermore, to see the difference between each group, Duncan's advanced test was based on the average exudate volume's treatment group factor. There were five different subsets with a value of significance of $1,000(p>0.05)$, each test set having a noticeable difference between each other.

As for calculating the total number of leukocytes against inflammatory mice, a decrease in the total number of leukocytes from the five experimental animal groups can be seen in Figure 3. The largest decline in the total number of leukocytes was in the gel extract concentration of $2 \%$, which was $9650.00 / \mu \mathrm{L}$ exudate.

On examining the total number of leukocytes mice, the test results of the total number of leukocytes with one-way ANOVA show sig results. $0,000(\mathrm{P}<0.05)$. The value indicates that the treatment group factor exerts a meaningful influence on the total number of mice leukocytes. Furthermore, to see the differences between each group, Duncan further test was conducted.

Based on the data analysis, the administration of gel can have a decreased effect on the volume of exudate and the total number of leukocytes in inflammatory mice as the concentration increases. This is because one of the compounds contained in Hydrocotyle sibthorpioides Lam. is flavonoids having pharmacological activity as an anti-inflammatory. The anti-inflammatory activity of flavonoids due to the absence of benzopiron rings present in the structure of flavonoids can be bonded with cyclooxygenase enzymes and lipooxygenase. Flavonoids work by inhibiting the synthesis of prostaglandins. As a result, inflammatory mediators are inhibited and edema reduction occurs. ${ }^{14}$

In addition to measuring the volume of exudate and the total number of leukocytes against inflammatory mice, calculations of leukocyte cell types are also carried out. A photo of leukocyte cell types under a microscope can be observed in Figure 4, the leukocyte cells consisting of neutrophils, eosinophils, monocytes, and lymphocytes. Data on leukocyte cell types can be seen in the graph shown in Figure 5. Based on the results of the one-way ANOVA analysis in Table 6, it is known that topical application of dew gel extracts significantly affected the number of stem neutrophil cells, segment neutrophils, and monocytes significantly $(\mathrm{P}<0.05)$ and were not significant for eosinophil cells and lymphocytes $(\mathrm{P}>0.05)$. Furthermore, after Duncan's further test on the number of stem neutrophil cells, segments, and monocytes, it turned out that the difference in concentration did not significantly affect the number of the three cells $(\mathrm{p}<0.05)$.

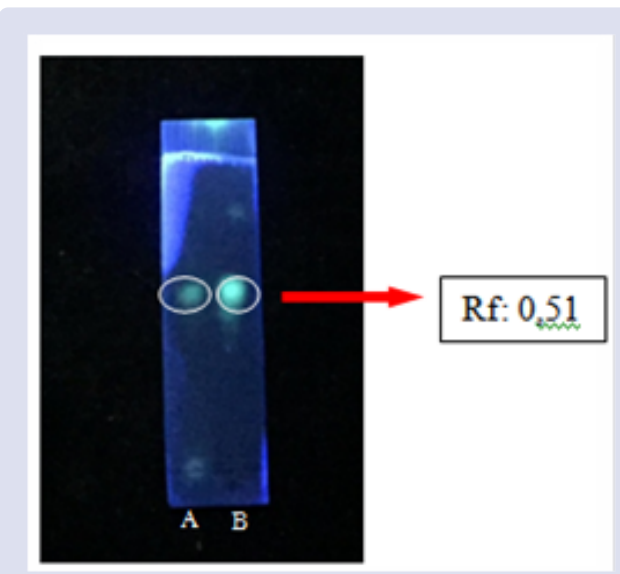

Figure 1: Profile TLC of Hydrocotyle sibthorpioides Lam. extract under UV light $254 \mathrm{~nm}$.

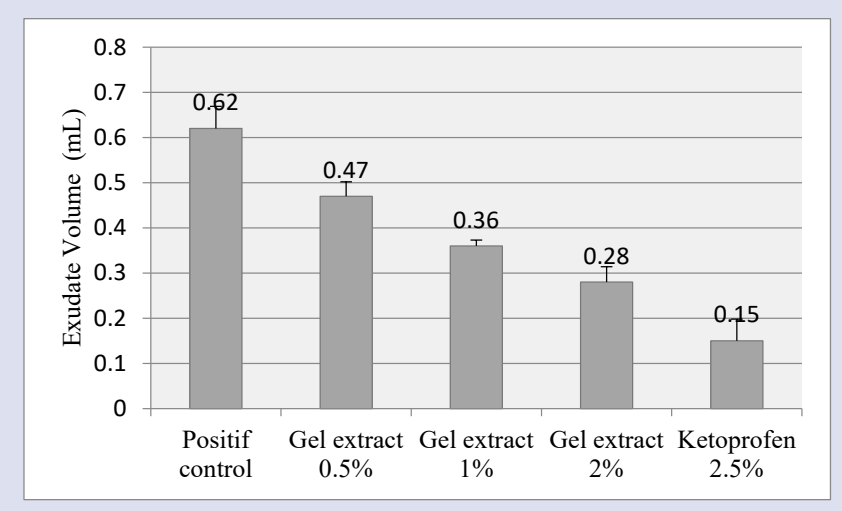

Figure 2: Diagram of the average volume of exudate after topical administration of gel in inflammatory mice.

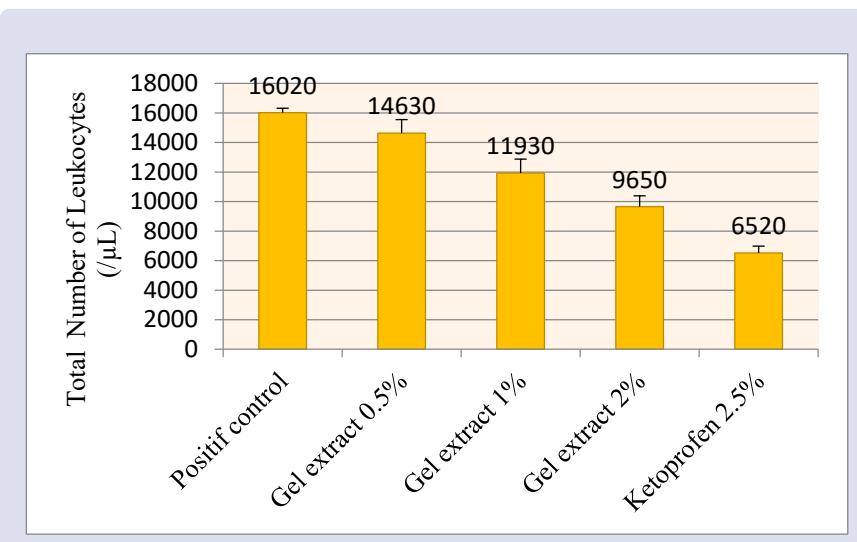

Figure 3: Diagram of average total Number of leukocytes after topical administration of gel in inflammatory mice.

Duncan's follow-up test then followed the data to see the differences in each group that can be seen in. The results showed the percentage of leukocyte cells after receiving Hydrocotyle sibthorpioides Lam. extract gel cells decreased for neutrophil cells. With the introduction of gelcontaining enzymes, Hydrocotyle sibthorpioides Lam. extract is able to provide a recovery effect on inflammatory conditions, resulting in a decrease in the number of neutrophil cells that are the main leukocyte cells that play a role in the acute inflammatory response. 


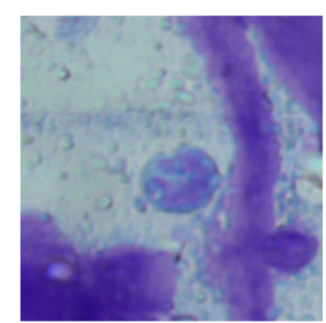

(a)

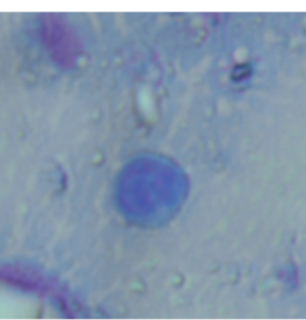

(b)

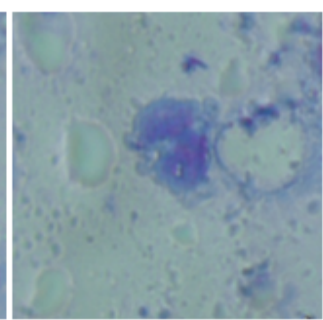

(c)

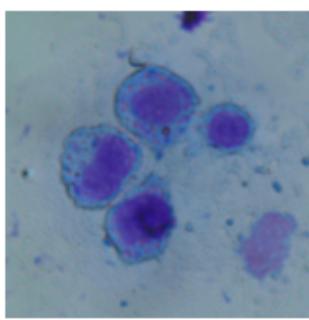

(d)

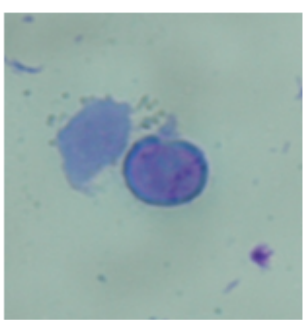

(e)

Figure 4: Photo Leukocyte cells from exudate mice that are inflammatory by $2 \%$ carrageenan after administering gel cells under a microscope enlarged 1000 times. Description: (a) Neutrophil stem, (b) Neutrophil segment, (c) Eosinophils, (d) Monocytes,

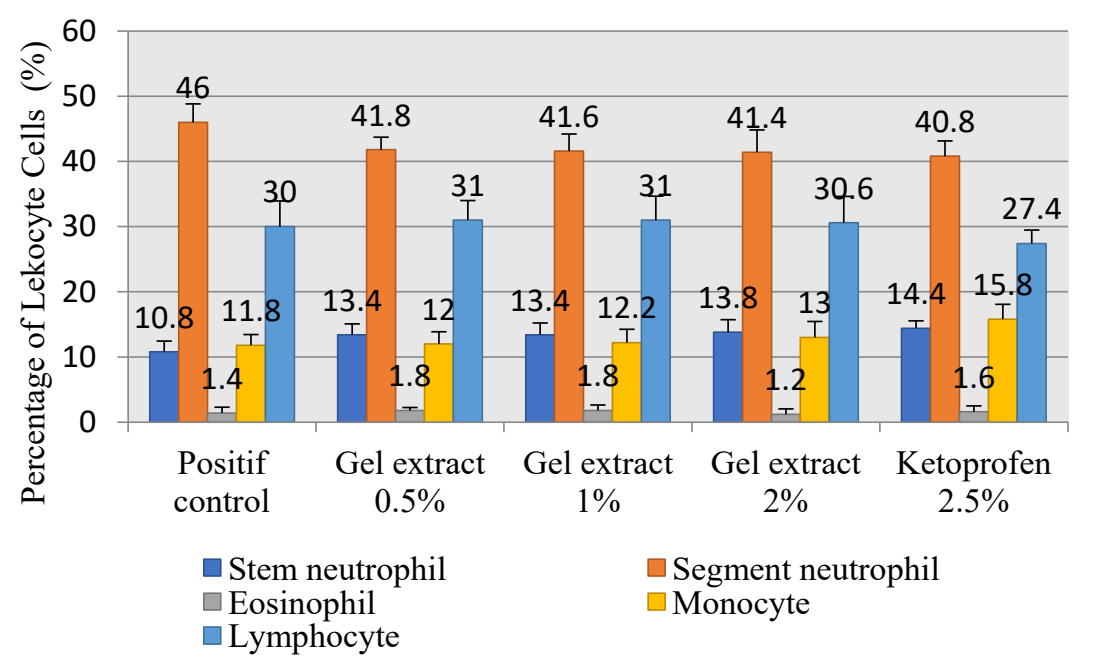

Figure 5: Diagram of the calculation of leukocyte cell type from exudate on the back of mice after topical administration of gel in inflammatory mice.

\section{CONCLUSION}

Based on the anti-inflammatory activity test results using the granuloma pouch method, it can be concluded that the gel use of $0.5 \%, 1 \%$, and $2 \%$ topically can provide an anti-inflammatory effect. The decrease of the exudates volume and the number of total leukocytes most large indicated by using gel extract of Hydrocotyle sibthorpioides Lam. $2 \%$. Besides, the percentage of leukocyte cell types also showed a decrease in the segmented neutrophil cells in inflammatory mice.

\section{ACKNOWLEDGMENT}

Profound thanks towards the Research Institution and Community Service (LPPM) of Andalas University that has funded this research.

\section{CONFLICTS OF INTEREST}

There is no conflicts of interest in this study. 


\section{REFERENCES}

1. Kusuma FR, Zaky BM. Tumbuhan liar berkhasiat obat. Jakarta: Agromedia pustaka; 2005.

2. Badrunasar A, Santoso HB. Tumbuhan Liar Berkhasiat Obat. Jilid III. Rachman E, Siarudin M, editors. Forda Press; 2016.

3. Anas B Harry BS. TUMBUHAN LIAR BERKHASIAT OBAT. Bandung: Forda Press; 2016.

4. Quamar MF Bera SK. Ethno-Medico-Botanical Studies of Plant Resources of Hoshangabad District, Madhya Pradesh, India: Retrospect and Prospects. 2014;1(1):1-11.

5. Mandal M Paul S Uddin MR Mondal MA Mandal S Mandal V. In vitro antibacterial potential of Hydrocotyle javanica Thunb. Asian Pacific J Trop Dis. 2016;6(1):54-62.

6. Asakawa Y, Matsuda R, Takemoto T. Mono- and sesquiterpenoids from Hydrocotyle and Centella species. Phytochemistry. 1982;21(10):2590-2.

7. Matsushita A. Hydrocotylosides I-VII, New Oleanane Saponins from Hydrocotyle sibthorpioides. Available from: https://pubs.acs.org/ doi/10.1021/np030356z
8. Dwiatmaka Y. Identifikasi flavonoid herba pegagan embun (Hydrocotyle sibthorpioides Lmk.) hasil isolasi secara KLTP serta uj kemurniannya dengan HPLC. J Sains dan Teknol. 2010;13(2):167-77.

9. Departemen Kesehatan RI. Farmakope Herbal Indonesia Edisi I. Jakarta: Departemen Kesehatan Rl; 2008.

10. Arifin H, Silvia R, Ifora. Efek Antiinflamasi Krim Ekstrak Etanol Daun Kirinyuh (Chromolaena odorata (L) R.M. King \& H. Rob) Secara Topikal dan Penentuan Jumlah Sel Leukosit Pada Mencit Putih Jantan. J Farm Higea. 2017;9(1):68-76.

11. Aldi Y, E Husni, R Yesika, Activity of Kincung Flowers (Etlingera Elatior (Jack) R.M.Sm.) on Total Leukocytes and Percentage of Leukocytes in Allergic Male White Mice. Pharmacogn J. 2020;12(1):44-51.

12. Y. Aldi, D. Dillasamola, T. Florina, and F. Ismed, "Test immunomodulatory effects of ethanol extract skin of purple sweet potato (Ipomoea batatas (L.) Lam) with carbon clearance method and the number of leukocytes," Res. J. Pharm. Biol. Chem. Sci., vol. 7, pp. 178-186, September-October 2016.

13. Stahl E. Thin-Layer Chromatography: A Laboratory Handbook. Springer; 2013

14. Robinson T. Kandungan Organik Tumbuhan Tinggi. Edisi ke-4. Bandung: ITB Press; 1995.

\section{GRAPHICAL ABSTRACT}

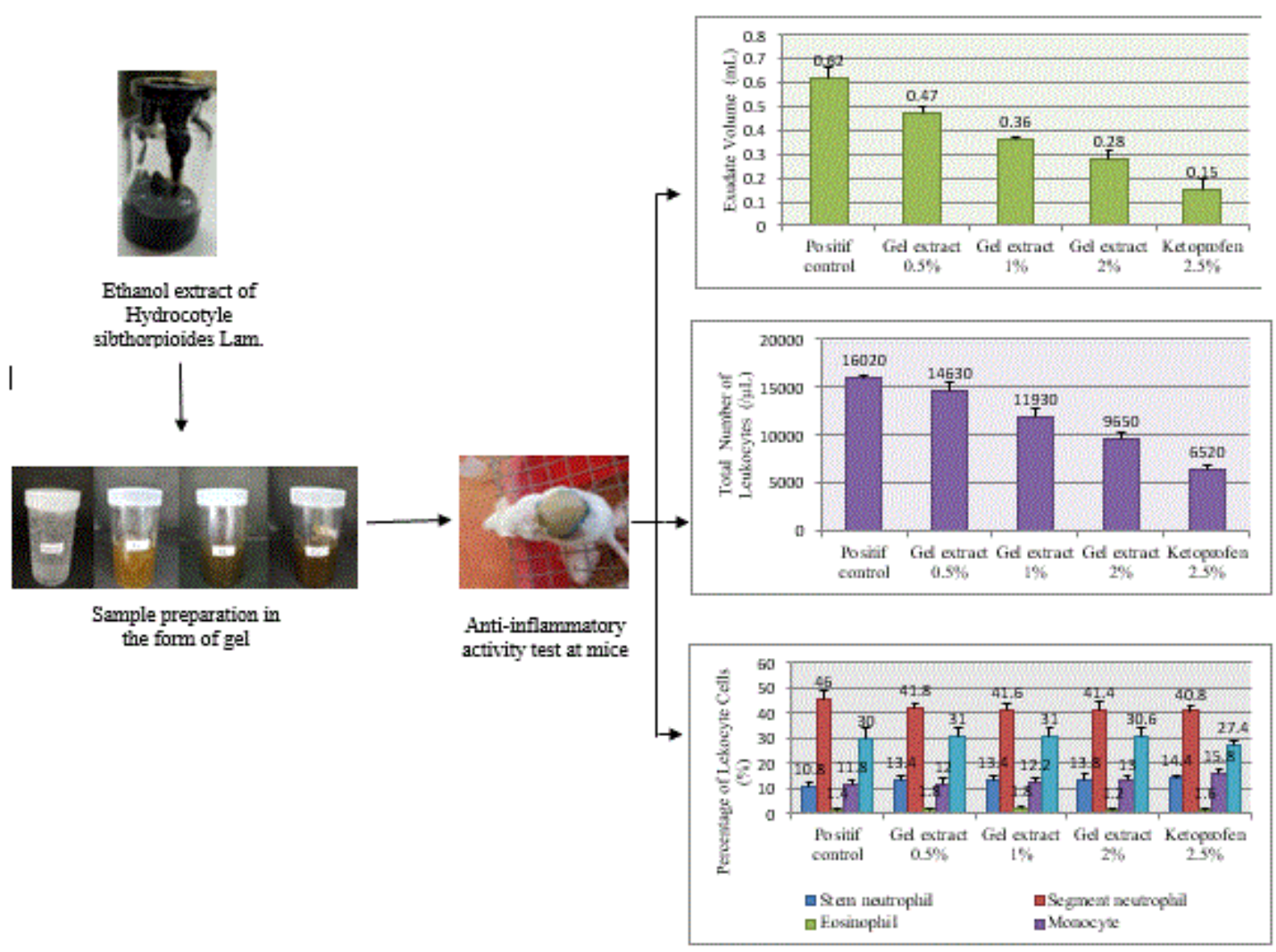




\section{SUMMARY}

Pegagan embun (Hydrocotyle sibthorpioides Lam.) is traditionally known to have many benefits, including anti-inflammatory. This study aims to determine the activity of ethanol extract of pegagan embun as an anti-inflammatory using the granuloma pouch method. This experimental used 25 male white mice and were divided into five groups, namely, the positive control group was given a gel base, the test group was given pegagan embun extract with concentration $0.5 \%$; $1 \%$; $2 \%$, and therefore the comparison group was given Kaltrofen ${ }^{\circledR}$ gel containing $2.5 \%$ ketoprofen. Experimental animals were given carrageenan $2 \%$ - induced inflammation subcutaneously. The dosage form was given as much as $0.2 \mathrm{~g}$ topically for 4 days once a day.

The observations showed that the most significant decrease within the volume of exudates was pegagan embun extract gel with a concentration of $2 \%, 0.28 \mathrm{~mL}$. Within the average total number of leukocytes, the most significant decrease within the total number of leukocytes was pegagan embun extract gel with a concentration of $2 \%, 9650.00 / \mu \mathrm{L}$. In the average percentage of leukocyte cells, the most significant decrease of segment neutrophil was within the animals that received pegagan embun extract gel with concentration $2 \%, 41.40 \%$, while in monocyte cells, the most significant increase was within the animals that received pegagan embun extract gel with concentrations $2 \%, 13.00 \%$.

Based on the results of one-way ANOVA analysis and Duncan's test, variations in concentration showed significant differences in exudate volume and total leukocytes $(p<0,05)$. At the same time, the percentage of leukocyte cells showed that they were not significantly different $(p>0,05)$. But the quantity of neutrophil cells was decreased. From the overall data obtained, it can be concluded that the extract of pegagan embun at concentrations $0,5 \% ; 1 \% ; 2 \%$, has an anti-inflammatory effect.

Pegagan embun (Hydrocotyle sibthorpioides Lam.) is traditionally known to have many benefits, including anti-inflammatory. This study aims to determine the activity of ethanol extract of pegagan embun as an anti-inflammatory using the granuloma pouch method. The parameters observed in anti-inflammatory activity were the volume of edema, the total number of leukocytes cells and the percentage of leukocytes cells in the inflammation mice. This experimental used 25 male white mice and were divided into five groups, namely, the positive control group was given a gel base, the test group was given pegagan embun extract with concentration $0.5 \% ; 1 \% ; 2 \%$, and therefore the comparison group was given Kaltrofen® gel containing $2.5 \%$ ketoprofen.. Experimental animals were given carrageenan $2 \%$ - induced inflammation subcutaneously. The dosage form was given as much as $0.2 \mathrm{~g}$ topically for 4 days once a day.

Based on the results of one-way ANOVA analysis and Duncan's test, variations in concentration showed significant differences in exudate volume and total leukocytes $(p<0,05)$. While the percentage of leukocyte cells showed that were not significantly different $(p>0,05)$. but the quantity of neutrophil cells was decrease. From the overall data obtained, it can be concluded that the extract of pegagan embun at concentration $0,5 \% ; 1 \% ; 2 \%$, has an anti-inflammatory effect.

\section{ABOUT AUTHORS}

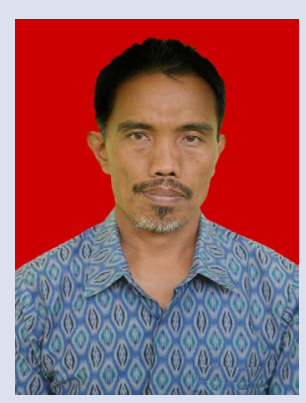

Dr. dr. Afriwardi, Sp.KO.: Born in Padang Kandis at 21 April 1967. Completed his education in Medicine Faculty in 1994 at Universitas Andalas, and his Specialist in Sports Medicine in Universitas Indonesia (2001) also the Doctoral Program in Biomedical Science at Universitas Andalas (2010). Currently, he is a lecturer in the Physiology Section of the Faculty of Medicine Universitas Andalas and has been a Dean at the Faculty of Dentistry of Universitas Andalas. His research interest in physiology and biomolecular research.

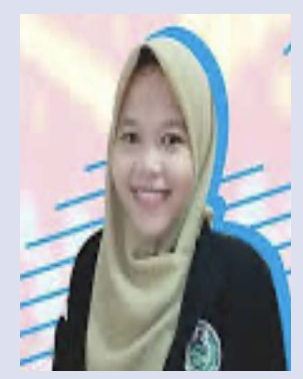

Rahmatul Nazmi: She is a student at the Faculty of Pharmacy of Andalas University who has been involved in research that studies the activity of anti-inflammatory topically. 


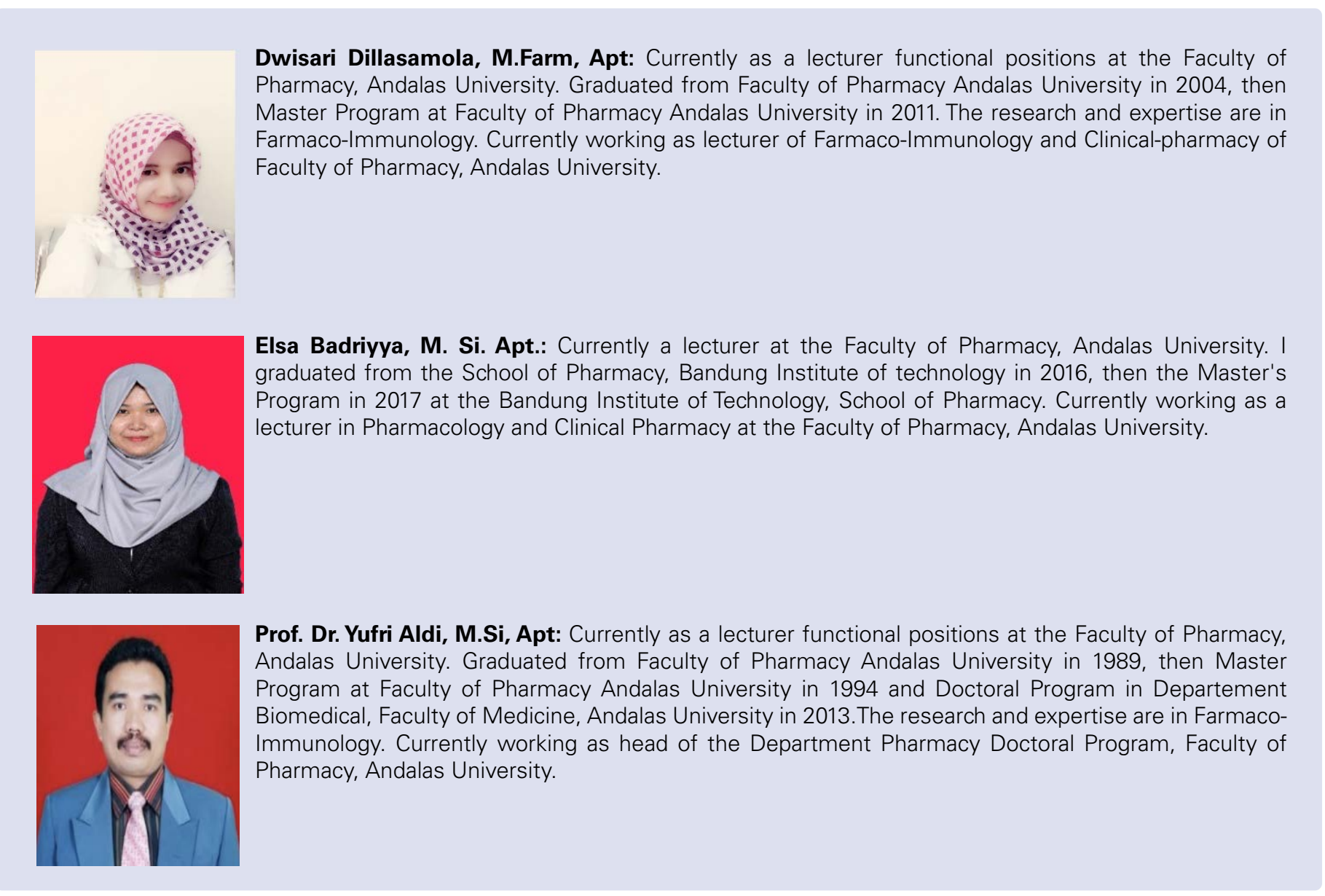

Cite this article: Afriwardi, Nazmi R, Dillasamola D, Badriyya E, Aldi Y. Anti-inflammatory Activity of Pegagan Embun (Hydrocotyle sibthorpioides Lam.) Plant Extract on Topical Application. Pharmacog J. 2021;13(2): 411-7. 